\title{
Transmedia Narrative Applied to the Final Degree Projects of the Eram/Udg Audiovisual and Multimedia Degree
}

\author{
Arnau Gifreu-Castells, \\ ERAM/Universitat de Girona - Spain,
}

Miquel Bisbe Fraixinó,

ERAM/Universitat de Girona - Spain

\begin{abstract}
In this work, we first describe the teaching method applied in two degrees (GAM and GAE) taught at ERAM, a school attached to the Universitat de Girona. We then discuss the particular characteristics of the group and individual final degree projects. Below we list the transmedia projects produced by the students during the period 2013-2017 in different areas (fiction, nonfiction and business), and choose a representative case study from each of these three areas. This makes it possible to determine a set of methodological implementations and innovations, both formal and in terms of contents, which we discuss in the present work.
\end{abstract}

Keywords: ERAM - Universitat de Girona - Audiovisual - Multimedia - Final Degree Project - Transmedia projects

\section{Introduction}

The University School ERAM is a centre attached to the Universitat de Girona that has been committed since 2013 to expanding audiovisual projects through transmedia narrative. After completing three initial courses that combine audiovisual and multimedia theory and practice, in the fourth and final year of the Degree in Audiovisual and Multimedia (GAM), the students must develop two final degree projects: one in a group and one individual. During the first semester of the fourth year, all the subjects are related and interconnected to foster this aim. The students are then asked to think of, design and develop in groups a transmedia project of fiction, non-fiction, a transmedia company or other related format.

In this paper, we first discuss using digital technology in classrooms and especially using practical projects to stimulate learning. Secondly, we describe the teaching methodology employed at ERAM, the particular education philosophy applied in two degrees (GAM and GAE) and the features of the final group and individual works. In the second part of the article, we describe the group transmedia projects developed during the period 2013-2017 and analyse three proposals as case studies: 2puntllibre (2013), Animal Hero (2015) and Lia (2017). The aim of this paper is to illustrate the importance of practical work in audiovisual and multimedia studies and of collaboration between different roles to produce multimodal and interactive narratives.

\section{Using technology in the classroom and for developing projects}

In recent years, several experts and studies have highlighted the growing importance of including technology in the current education systems to promote new skills in students, enhance their abilities and prepare them for the global economy and information society (Haddad and Draxler, 2002; Wagner et al., 2005; Wagner and Kozma, 2005; Kozma, 2005). In this work, we consider it important to give an introduction to obtaining digital skills in the classroom, since many of the ERAM subjects use the new digital technologies as tools for mediation and representation, and the expression of these subjects and the use of these tools, which are translated into ambitious transmedia projects, are managed from complex technological platforms and supports.

According to Pérez Tornero (2009), the development and use of ICT has led the European Union to promote media literacy inside and outside the classroom and stimulate the creative and critical skills of citizens in relation to communication media. 
Consequently, one of the priority areas of the 'Strategic Framework for Education and Training 2020' is the promotion of creativity and innovation through the use of new ICT tools as well as teacher training (Eurydice, European Commission, 2011).

In this regard, the European Union has for some years made a major effort to promote connectivity in the classroom and give young people access to new technologies (European Commission, 2007). In 2010, the European Commission adopted a new Digital Agenda for Europe (European Commission, 2010) aimed at maximizing the social and economic potential of ICTs, which required the development of high-level ICT skills, including digital and media literacy (Eurydice, European Commission, 2011). To this we need to add numerous national policies that reinforced this strategy and provide many European countries with the tools and training necessary for providing young people with digital literacy.

According to Cobo and Moravec (2011), one of the examples that has managed to break the traditional higher-education model is the university model called peer-to-peer (P2PU), which incorporates principles of collective intelligence adopted by Wikipedia and free software 2.0 and takes them to the field of education. This initiative proposes a university in a global environment that offers open contents, short courses of a few weeks and project-based learning programs with contents related to the technologies and demands of the industrial sector.

In this experimental context, and according with Torres Menárguez (2016), Minerva (United States), Kaospilot (Denmark) and Hyper Island (Sweden) are some examples of universities that apply alternative teaching methods. They base their methodologies on trial and error processes and on the students' own experience. In the case of Minerva, lectures are considered ineffective as they believe that it is not easy for students to internalize concepts explained as unidirectional messages transmitted by the teacher. Instead, they encourage discussions and debate on a subject, application of concepts in practical work, comments on results with other students, evaluation with hands-on projects and questionnaires that are automatically corrected in an online platform designed to promote interaction between teachers and students. To all this we must add the mobility of the students: during the first year they live in a residence in San Francisco, but from the second year on the geographical location changes and they move to Buenos Aires and Berlin; in the third, to Bangalore and Seoul; and in the fourth, to Istanbul and London. Getting to know a new country, language and culture could be essential in these new models (Torres Menárguez, 2016).

Kaospilot can be considered an innovative school somewhere between design and business, with a methodology aimed at promoting leadership and entrepreneurship. Inaugurated in 1991 in Aarhus, Denmark, sixteen years after it began, Businessweek magazine referred to it as one of the best design schools in the world. Four years later, Fast Company included it in the top ten schools in the world within the start-up ecosystem, that is, emerging technology-based companies. The minimum age to apply for a place at the university is twenty-one, and values and interests are valued over the grading system. Its model prioritizes practice, then reflection, and lastly theory (Torres Menárguez, 2016).

Finally, Hyper Island (Sweden) is a project housed in a former prison on the Swedish island of Stumholmen. Students are aged between nineteen and sixty. Communication and digital design are the backbone of learning at this university, which offers specializations such as art director for interactive media, creative mobile technology and digital company expert. The teachers, who are called 'facilitators', are active professionals in companies that are leaders in emerging trends, such as Spotify. In this program, everything moves to the rhythm of the industry, in a simulation of a real professional scenario (Torres Menárguez, 2016).

Several of these models and premises are also applied at ERAM, as we will analyse below (work and assessment with practical projects, mobility of students, an environment close to the professional field, interests and motivation of students, etc.).

\section{The ERAM School}

Located in the Coma Cros de Salt (Girona) Cultural Facilities, the ERAM University School (EU ERAM) is a centre for interdisciplinary studies attached to the Universitat de Girona and linked to communication studies and the arts. It is committed to transdisciplinary and creative training oriented towards the professional world. There are two official degrees taught at the centre with a unique curriculum, the Degree in Audiovisual and Multimedia (GAM) and the Degree in Performing Arts (GAE), as well as different diplomas and specialization courses. 
The centre, a pioneer in Girona in audiovisual, multimedia and design studies, is integrated into the social and industrial fabric that surrounds it, leading the sectors for which it educates students.

The teaching team, made up of doctors, graduates and specialized professionals, comes from different fields related to audiovisual communication, culture, art, music, journalism, cinema, television, design, advertising, multimedia and history. The team works with an open and integrated understanding of knowledge to generate a creative and personalized learning space conducive to the personal and professional growth of all the students of ERAM. The school's main differential factors can be summarized in the following points:

\begin{tabular}{|c|c|}
\hline Differential factor & Justification \\
\hline Quality of teaching & $\begin{array}{l}\text { GAM and GAE are official university studies that meet all the } \\
\text { standards established by AQU Catalunya (Agency for the } \\
\text { Quality of the University System of Catalonia) and, therefore, } \\
\text { are recognized degrees in Europe. }\end{array}$ \\
\hline Creativity & $\begin{array}{l}\text { The curriculum of the Degree in Audiovisual and Multimedia } \\
\text { (GAM) has twenty credits (two hundred hours) of creativity } \\
\text { subjects. }\end{array}$ \\
\hline Innovation & $\begin{array}{l}\text { The school is a pioneer in multidisciplinary education in the } \\
\text { audiovisual and multimedia field. In addition, it stands out as the } \\
\text { only school in Catalonia that teaches GAE studies (performing } \\
\text { arts and scenic creation) in an official university setting. }\end{array}$ \\
\hline Professionalism & $\begin{array}{l}\text { Both GAM and GAE are studies orientated towards the } \\
\text { professional world. Practical and theoretical subjects are taught } \\
\text { simultaneously from the very first course. }\end{array}$ \\
\hline Transversality & $\begin{array}{l}\text { Since its beginning the school has been committed to holistic } \\
\text { teaching founded in multidisciplinarity. The GAM curriculum is } \\
\text { based on several interrelated subjects (transversality). }\end{array}$ \\
\hline Proximity & $\begin{array}{l}\text { Students are offered not only the infrastructures and the } \\
\text { appropriate teaching staff, but also close, familiar and } \\
\text { personalized treatment. }\end{array}$ \\
\hline Work placement & $\begin{array}{l}\text { The studies are directed towards the maximum employability of } \\
\text { the students. This is demonstrated in the latest survey carried } \\
\text { out by AQU Catalunya: } 100 \% \text { of the students who have } \\
\text { completed the Degree in Audiovisual and Multimedia (GAM) are } \\
\text { currently employed. }\end{array}$ \\
\hline International alliances & $\begin{array}{l}\text { The school has made a strategic commitment to } \\
\text { internationalization. It has made international agreements so } \\
\text { that the students can benefit from the European Erasmus } \\
\text { programs, and the school offers the opportunity of taking a } \\
\text { double degree (top-up) at a foreign university. }\end{array}$ \\
\hline
\end{tabular}

Figure 1. Differential factors at ERAM School

Once students have completed the Degree in Audiovisual and Multimedia, they are offered the opportunity to go directly into the third year of various bachelor degrees in England, and thus obtain a second official qualification in the specialization they wish. Based on the premise that internationalization empowers students to find better jobs and salaries, we have worked to offer new graduates the option of a fifth year $(4+1)$ at different English universities. 
The following is a summary of the specific profiles offered by GAM:

\begin{tabular}{|l|l|}
\hline AREA & SPECIFIC PROFILES \\
\hline $\begin{array}{l}\text { Audiovisual works, cinema } \\
\text { and television }\end{array}$ & $\begin{array}{l}\text { Direction, production, realization, cinematography, screenplay, camera, editing, colouring, } \\
\text { audiovisual design and motion graphics }\end{array}$ \\
\hline Videogames & $\begin{array}{l}\text { Software engineering, programming, music design, audio design, postproduction, scripts, user } \\
\text { interface design, 3D modelling and animation }\end{array}$ \\
\hline Advertising & $\begin{array}{l}\text { Creative direction, art direction, graphic design, illustration, artwork, copywriting, account } \\
\text { management and media planning }\end{array}$ \\
\hline Digital communication & $\begin{array}{l}\text { Project management, community management, online marketing, SEO, SEM, digital strategy, } \\
\text { content management and editor }\end{array}$ \\
\hline Transmedia & $\begin{array}{l}\text { CEO technology, technology management, apps, web design, motion manager, crossmedia } \\
\text { management, programmer, database development, story design and concept art }\end{array}$ \\
\hline Photography & $\begin{array}{l}\text { Professional photographer, editorial, advertising, industrial and fashion, portrait, digital } \\
\text { retouching, laboratory, photography director, exhibition curator and artist }\end{array}$ \\
\hline Sound & $\begin{array}{l}\text { Audio design, musical design, sound technician, musical production, creation of musical } \\
\text { applications and postproduction of multimedia projects }\end{array}$ \\
\hline Design & $\begin{array}{l}\text { Graphic design, branding, editorial design, advertising design, packaging, environment design, } \\
\text { typographic design, management design }\end{array}$ \\
\hline 3D & $\begin{array}{l}\text { Animation, modelling, design of special effects, character design, graphics, texturing, lighting, } \\
\text { postproduction and motion grapher }\end{array}$ \\
\hline Art & $\begin{array}{l}\text { Visual arts, art criticism, curating exhibitions, documentary, storyboard artist and cultural } \\
\text { management }\end{array}$ \\
\hline
\end{tabular}

Figure 2. Specific profiles of GAM students at ERAM

\section{Development of the group final degree project in the 4th GAM course}

The GAM Audiovisual Degree offers a practical approach to students from the very first year. This differentiates it from other Communication Degrees, which generally have more theoretical and transversal content with journalism. In addition, thanks to this intensive technical training, in the last year the students develop two final degree projects, one group project and one individual project, as well as attending complementary seminars, internships or professional work outside the centre.

During the first semester of the fourth year (September-February), students think of, design and develop a transmedia project of fiction, non-fiction, a transmedia company or another format. Groups consist of 6-8 students who work together following a model that is very like the professional model. There are supervisors for each area from a group of seven teachers who ensure the feasibility and quality of the projects which are developed in a very short time period. Honey and Mumford (1986 and 1992) have found that students show a combination of four learning styles:

a) Activists: people who manifest an active style participate and commit fully and without prejudice to new experiences. They grow in the face of challenges and get bored with tasks that take a long time. They are people who enjoy being in a group, who get involved in the affairs of others and focus all activities around them.

b) Reflectors: these students also learn from new experiences but do not like being directly involved in them. They gather data and analyse them carefully before reaching any conclusions. They enjoy observing the performance of others, listening to them, but they do not intervene until they fully understand the situation.

c) Theorists: theoretical students learn best when the things that are taught are part of a system, model, theory or concept. They like to analyse and synthesize. For them, logical is synonymous to good. 
d) Pragmatists: for these students, the key lies in the practical application of ideas. They discover the positive aspects of new ideas and take the first opportunity to experience them. They tend to be impatient when there are people who theorize.

The student groups formed to carry out the final transmedia group work cover these four styles, which allows considerable interaction and flow between the different departments. Ultimately, this structure makes it possible to form and manage multidisciplinary groups of 15-20 people, including students, teachers and professionals. The following formula is used:

a) Groups of 6-8 students are formed in which each student chooses a certain profile. These profiles are divided into two main areas:

\begin{tabular}{|l|l|}
\hline Audiovisual & Multimedia \\
\hline - Screenwriter & - Transmedia producer \\
- Producer & - Information Architect \\
- Director & - Designer \\
- Sound & - Web developer \\
- Art & - Textual and audiovisual content \\
\hline
\end{tabular}

Figure 3. Group profiles by area (audiovisual and multimedia)

b) Weekly tutoring from six teachers who are experts in the different areas. The seven specific areas are:

\begin{tabular}{|l|l|}
\hline Specific area & 4th-year related subject \\
\hline 1. General coordination & All project subjects \\
\hline 2. Coordination of the audiovisual area & Audiovisual realization project (6 credits) \\
\hline 3. Pre-production (script) and production & Audiovisual realization project ( 6 credits) \\
\hline $\begin{array}{l}\text { 4. Postproduction (editing) and visual effects } \\
\text { (VFX) }\end{array}$ & Audiovisual design project (3 credits) \\
\hline 5. Sound & Digital sound design and creation project (3 credits) \\
\hline 6. Coordination of the transmedia area & Multimedia communication project $(9$ credits) \\
\hline 7. Design & Graphic design and communication project (3 credits) \\
\hline
\end{tabular}

Figure 4. Specific areas and their respective subjects

c) Support in web development (programming) from two teachers from the centre.

d) Alliances with other courses.

e) Support from the school for presenting projects at festivals and for prizes.

f) Additional work in the ERAM laboratory Medialab to enhance and refine projects.

The aim of creating such broad groups in the fourth year of GAM is precisely to mix and study how different student learning styles can be managed as a foundation for learning through projects. The nature of each project is considered a complex problem to be solved (what is the best way to tell a story with the technological media?) in a limited time period (12 weeks) based on complex organization (coordination between functions and periodical tutorials with the various teachers involved). The students present the developed project in front of the team of teachers and the other students as the final outcome.

Throughout the process, the teachers involved hold monthly meetings. During the final assessment meeting, teachers decide:

a) Which projects are appropriate for further development with the support of ERAM

Medialab.

b) Which projects can compete at a local level: University-Industry Audiovisual Pitching,

comUNIca grants, audiovisual festivals in Girona and Barcelona, etc.

c) Which projects can compete at the international level. 
d) Evaluate other possibilities and strategies for developing projects further.

\section{Projects developed during the period 2013-2017}

Below we list the 19 transmedia projects produced during the period 2013-2017 at ERAM. Two separate tables show (Table 1) the names of the projects, the students and technical information (format, genre, URL and production year), and (Table

2) the description and the platforms that make up the transmedia narrative:

\begin{tabular}{|c|c|c|}
\hline Project & Theme - Students & Format, genre and year \\
\hline 2Puntllibre & $\begin{array}{l}\text { Isaura Creus, Ferran Company, Mireia Casajuana, Noemi } \\
\text { Roset, Sara Pascual, Jaume Serradelarca and Gerard } \\
\text { Tarrats }\end{array}$ & $\begin{array}{l}\text { Alternate Reality Game, fiction, } 2014 \\
\text { http://es.eram.cat/showroom/2- } \\
\text { puntllibre/ }\end{array}$ \\
\hline Ciao Mamma & $\begin{array}{l}\text { Alex Casas, Jordi Fornells, Edgar Hugas, Claudia Leria, } \\
\text { Xavier Masias, Jordi Massó and Maria Palacios }\end{array}$ & $\begin{array}{l}\text { Transmedia project, magazine, } 2014 \\
\text { http://en.eram.cat/showroom/ciao- } \\
\text { mamma-project/ }\end{array}$ \\
\hline Pato Mareado & $\begin{array}{l}\text { Laura Agustí, Sergi Busquets, Joan Surís, Àlex Serra, David } \\
\text { Gutiérrez and Dely Ponce }\end{array}$ & $\begin{array}{l}\text { Transmedia project, company, } 2014 \\
\text { http://es.eram.cat/showroom/pato- } \\
\text { mareado-bcn/ }\end{array}$ \\
\hline Un buen hombre & $\begin{array}{l}\text { Anna Villar, Aina Balsells, Marc Falgàs, Oriol Amargant, } \\
\text { Martí Palazón, Mireia Teixidor and Sara Vicente }\end{array}$ & $\begin{array}{l}\text { Transmedia project, fiction, } 2014 \\
\text { http://es.eram.cat/showroom/un- } \\
\text { buen-hombre/ }\end{array}$ \\
\hline Dirty Dishes & $\begin{array}{l}\text { Alex Boix, Mariona Boada, Raquel Bosch, Francesc Rosado, } \\
\text { Marc Suria and Josep Oriol Valentí }\end{array}$ & $\begin{array}{l}\text { Transmedia project, fiction, } 2014 \\
\text { http://es.eram.cat/showroom/dirty- } \\
\text { dishes/ }\end{array}$ \\
\hline Infectio & $\begin{array}{l}\text { Oriol Jiménez, Oriol Costa, Deli Ponce, Guillem Tarrés, } \\
\text { Berta Nicolau, Sara Rodríguez and Pep Roca }\end{array}$ & $\begin{array}{l}\text { Transmedia project, fiction, } 2015 \\
\text { http://infectioproject.com/es/ }\end{array}$ \\
\hline La sopa boba & $\begin{array}{l}\text { Víctor Piella, David Ruiz, Marc Font, Jordi Puig, Gina Mills, } \\
\text { Eva Torrent and Mireia Reinal }\end{array}$ & $\begin{array}{l}\text { Transmedia project, fiction, } 2015 \\
\text { ERAM Showroom: } \\
\text { http://en.eram.cat/showroom/la-sopa- } \\
\text { boba/ }\end{array}$ \\
\hline Això nostre & $\begin{array}{l}\text { Helena Corbera, Marc Auladell, Albert Sánchez, Laia Font, } \\
\text { Ivette Serrallonga and Àngels Teixidor }\end{array}$ & $\begin{array}{l}\text { Transmedia project, nonfiction, } 2015 \\
\text { http://es.eram.cat/showroom/aixo- } \\
\text { nostre/ }\end{array}$ \\
\hline Animal Hero & $\begin{array}{l}\text { Silvia Quera, Yolanda Peregrín, Anna Vila-Clara, Vanessa } \\
\text { Pujol, Alba Bosacoma and Aniol Batallé }\end{array}$ & $\begin{array}{l}\text { Transmedia project, nonfiction, } 2015 \\
\text { http://en.eram.cat/showroom/animal- } \\
\text { herol }\end{array}$ \\
\hline Mevent & $\begin{array}{l}\text { Miquel Alzina, Pol Amadó, Maria Badia, Sara Cabarrocas, } \\
\text { Josep Cuberes, Mariona Escriu, Maria Roca and Salvador } \\
\text { Maynou }\end{array}$ & $\begin{array}{l}\text { Transmedia project, company, } 2016 \\
\text { http://en.eram.cat/showroom/mevent- } \\
\text { project/ }\end{array}$ \\
\hline Bemotion & $\begin{array}{l}\text { Daniel Casanovas, Irene Gironès, Roger Juanola, Helena } \\
\text { Martínez, Mireia Masgrau, Irene Ponsatí, Cristina Quinta and } \\
\text { Anna Saula }\end{array}$ & $\begin{array}{l}\text { Transmedia project, company, } 2016 \\
\text { http://en.eram.cat/showroom/bemotio } \\
\text { n-events/ }\end{array}$ \\
\hline $\begin{array}{l}\text { Desenterrant el } \\
\text { negre }\end{array}$ & $\begin{array}{l}\text { Gerard Hugas, Roger Bisbe, Daniel Álvarez, David Porras, } \\
\text { Mònica Sala, Aida Pérez, Albert Garanger and Antonia } \\
\text { Antequera }\end{array}$ & $\begin{array}{l}\text { Transmedia project, nonfiction, } 2016 \\
\text { http://www.desenterrantelnegre.cat/ }\end{array}$ \\
\hline Frikisados & $\begin{array}{l}\text { Claudia Bolte, Adrià Casanovas, Mar Coll, Joan Muñoz, } \\
\text { Rubén Lozano, Adrià Llauró, Andrea Nicolás and Nidia } \\
\text { Martin }\end{array}$ & $\begin{array}{l}\text { Transmedia project, fiction, } 2016 \\
\text { http://en.eram.cat/showroom/frikisado } \\
\underline{\text { s/ }}\end{array}$ \\
\hline Antítesis & $\begin{array}{l}\text { Ariadna Oliver, Marc Clemente, Joan Congost, Aida López, } \\
\text { Jaume Duran, Pau Casas, Mireia Riera and Enric Riera }\end{array}$ & $\begin{array}{l}\text { Transmedia project, fiction, } 2016 \\
\text { http://en.eram.cat/showroom/antitesis } \\
\text {-el-origen-de-un-antiheroe } \\
\end{array}$ \\
\hline
\end{tabular}




\begin{tabular}{|c|c|c|}
\hline Aire fresco & $\begin{array}{l}\text { Laura Soler, Pau Ensesa, Antoni Bach, Núria Casadevall, } \\
\text { Fran Martín, Laura Pinilla, Jordina Roura, Àlex Vicente and } \\
\text { Gemma Sirvent }\end{array}$ & $\begin{array}{l}\text { Transmedia project, fiction, } 2016 \\
\text { http://en.eram.cat/showroom/aire- } \\
\text { frescol }\end{array}$ \\
\hline Lia & $\begin{array}{l}\text { Eudald Rovira, Marc de la Fuente, Marta Viña, Marc } \\
\text { Carreres, Julià Pujol, Carla Font, Aniol Torrents, Pau Horta, } \\
\text { Idoia Iriarte }\end{array}$ & $\begin{array}{l}\text { Transmedia project, fiction, } 2017 \\
\text { http://en.eram.cat/showroom/lia/ }\end{array}$ \\
\hline Imego & $\begin{array}{l}\text { Joel Torrecabota, Xènia Torres, Karla Ruiz, Ana Zapata, } \\
\text { Pablo Fernández, Laia Fornaguera, Juan Manuel Mallet }\end{array}$ & $\begin{array}{l}\text { Transmedia project, company, } 2017 \\
\text { http://en.eram.cat/showroom/imego/ }\end{array}$ \\
\hline Lata de sardinas & $\begin{array}{l}\text { Nidia Andrea Martín, Anna Isabel Espinosa, Jordi Clopés, } \\
\text { Alejandro Maestra, Valeri Ballester, Marta Montaño, Maria } \\
\text { Dolors Moncayola, Judit Capell }\end{array}$ & $\begin{array}{l}\text { Transmedia project, nonfiction, } 2017 \\
\text { http://en.eram.cat/showroom/lata-de- } \\
\text { sardinas/ }\end{array}$ \\
\hline Ningun nombre & $\begin{array}{l}\text { Nuria Perez, Raquel Isern, Berta Font, Miriam Seguí, Pol } \\
\text { Masvidal, Cristina Ruiz, Judith Mallet, Saioa Arroyo, Albert } \\
\text { Estany, Ferran Higueruelo }\end{array}$ & $\begin{array}{l}\text { Transmedia project, fiction, } 2017 \\
\text { http://en.eram.cat/showroom/ningun- } \\
\text { nombre/ }\end{array}$ \\
\hline
\end{tabular}

Figure 5. Table with names of projects, students and technical information (format, genre, URL and production year)

The result shown in the table above indicates a predominance of fiction in student preferences (with a total of 10 projects), 4 nonfiction projects, 4 transmedia companies and 1 magazine (other related formats). In the following table, we will analyze the theme of each project and in what supports and platforms its content is diversified.

\begin{tabular}{|c|c|}
\hline Description & $\begin{array}{l}\text { Platforms } \\
\text { developed }\end{array}$ \\
\hline $\begin{array}{l}\text { 2Puntllibre. This project is halfway between an alternate reality game (ARG) and a } \\
\text { transmedia narrative. As a starting point, this type of narrative consists of fragmenting a } \\
\text { story and reproducing it in different supports, with the idea of linking, in this case, } \\
\text { literature and technology. The project starts from a short story that takes place in the city } \\
\text { of Girona. Each literary content was transmitted to multiple platforms: audiovisual, } \\
\text { illustration, interactive application, sound imaginary, performance, drawing, photography, } \\
\text { website and comic. }\end{array}$ & $\begin{array}{l}\text { - Website } \\
\text { - ARG } \\
\text { - Videos } \\
\text { - Social networks }\end{array}$ \\
\hline $\begin{array}{l}\text { Ciao Mamma. This project is a renovation of the magazine Ciao Mamma, that ERAM } \\
\text { originally developed. The magazine's lack of popularity among the ERAM students made } \\
\text { it necessary to renovate it, which is what this team of students did. }\end{array}$ & $\begin{array}{l}\text { - Online magazine } \\
\text { - Promotional videos } \\
\text { - Social networks }\end{array}$ \\
\hline $\begin{array}{l}\text { Pato Mareado. Juan Leon, founder and owner of Pato Mareado BCN (Dizzy Duck } \\
\text { Barcelona), got in touch with the creative studio Quagga (ERAM student group), with the } \\
\text { aim of boosting the brand and improving the product sales. The main idea of the brand is } \\
\text { to sell T-shirts that have fun, colourful illustrations with an underlying criticism on the } \\
\text { current world situation. }\end{array}$ & $\begin{array}{l}\text { - Corporate website } \\
\text { - Online shop } \\
\text { - Promotional videos (spots) } \\
\text { - Application for mobiles and } \\
\text { tablets }\end{array}$ \\
\hline $\begin{array}{l}\text { Un buen hombre. (A Good Man) When David finds some very important documents from } \\
\text { the pharmaceutical laboratories where he works, he must face the moral dilemma of } \\
\text { incriminating the company by bringing the documents to light or returning to the company } \\
\text { in order to save his family. His decision will directly affect his life and the people around } \\
\text { him. Starting from an audiovisual short film, the project expands to the web and other } \\
\text { formats. }\end{array}$ & $\begin{array}{l}\text { - Short film } \\
\text { - Website } \\
\text { - Social networks }\end{array}$ \\
\hline $\begin{array}{l}\text { Dirty Dishes. Carol should have come home three days ago. After trying to contact her } \\
\text { and realising she is missing, her father decides to go out and look for her to help the } \\
\text { police. Starting from an audiovisual short film, the project expands to the web and other } \\
\text { formats; It also proposes some innovative formats, such as a soundscape. }\end{array}$ & $\begin{array}{l}\text { - Short film } \\
\text { - Website } \\
\text { - Soundscape } \\
\text { - Social networks }\end{array}$ \\
\hline $\begin{array}{l}\text { Infectio. Transmedia fiction in a post-apocalyptic scenario where survivors of a nuclear } \\
\text { crisis must adapt to the new situation. }\end{array}$ & $\begin{array}{l}\text { - Short film } \\
\text { - Website } \\
\text { - Comic } \\
\text { - Social networks }\end{array}$ \\
\hline $\begin{array}{l}\text { La sopa boba. Transmedia fiction about a family in which the son neither } \\
\text { works nor studies (he is, what is known in Spain as, a nini). Everything comes }\end{array}$ & $\begin{array}{l}\text { - Short film } \\
\text { - Website }\end{array}$ \\
\hline
\end{tabular}




\begin{tabular}{|c|c|}
\hline to a head at an extremely tense family dinner. & $\begin{array}{l}\text { - App } \\
\text { - Social networks }\end{array}$ \\
\hline $\begin{array}{l}\text { Això nostre. Transmedia documentary about the values of rural schools, } \\
\text { focused on the specific case of the town of Osor (Girona). }\end{array}$ & $\begin{array}{l}\text { - Webdoc } \\
\text { - Exposition } \\
\text { - Social networks }\end{array}$ \\
\hline $\begin{array}{l}\text { Animal Hero. Educational transmedia documentary to stimulate skills in } \\
\text { children with Down syndrome. }\end{array}$ & $\begin{array}{l}\text { - Videogame Kinekt } \\
\text { - App } \\
\text { - Website } \\
\text { - Documentary } \\
\text { - Interactive doc } \\
\text { - Social networks }\end{array}$ \\
\hline $\begin{array}{l}\text { Mevent. A company that promotes other companies in an original, alternative } \\
\text { way. First an event is held that is appropriate for the company that is being } \\
\text { promoted. In this event, people in groups can win a prize that the company } \\
\text { provides. This reinforces the company's brand territory and branding. }\end{array}$ & $\begin{array}{l}\text { - Website } \\
\text { - ARG } \\
\text { - Merchandising } \\
\text { - Social networks }\end{array}$ \\
\hline $\begin{array}{l}\text { Bemotion. The main objective of this company is to incorporate new } \\
\text { technologies in events and acts in different fields. The main axis of this project } \\
\text { is the creation and development of the Bemotion company itself, and a } \\
\text { demonstration of what it does. }\end{array}$ & $\begin{array}{l}\text { - Website } \\
\text { - } 360 \text { Videos } \\
\text { - Performance } \\
\text { - Social networks }\end{array}$ \\
\hline $\begin{array}{l}\text { Desenterrant el negre. The story of the conflict triggered by the Bushy Man } \\
\text { toy, a full-scale reproduction of the well-known and controversial "Negro de } \\
\text { Banyoles" (Black man of Banyoles). A curse on the doll causes anyone who } \\
\text { comes into contact with it to become extremely selfish and power hungry. This } \\
\text { is a false transmedia documentary in which the initial action takes place in an } \\
\text { audiovisual piece of about } 15 \text { minutes. }\end{array}$ & $\begin{array}{l}\text { - Webdoc } \\
\text { - Short documentary film } \\
\text { - Social networks }\end{array}$ \\
\hline $\begin{array}{l}\text { Frikisados. Web series starring three failed adult frikis (freaks) who want to } \\
\text { turn their lives around by dedicating themselves to what they have always } \\
\text { dreamed of doing. Their particular freakishness, which makes them failures in } \\
\text { society, is precisely what will later lead them to triumph. The series therefore } \\
\text { plays with a sociocultural paradox. }\end{array}$ & $\begin{array}{l}\text { - Web series } \\
\text { - Website } \\
\text { - Social networks }\end{array}$ \\
\hline $\begin{array}{l}\text { Antitesis. The main element of this project is a fictional short film that tells the } \\
\text { story of Nico, a child who alters and distorts his reality due to his obsession } \\
\text { with superheroes. This obsession causes him to behave violently and } \\
\text { aggressively towards his father, who he finally attacks because of a mistake. A } \\
\text { short fiction film shows the origins of an anti-hero in an expanded narrative that } \\
\text { includes various media and platforms. }\end{array}$ & $\begin{array}{l}\text { - Short film } \\
\text { - Website } \\
\text { - Videogame } \\
\text { - Comic } \\
\text { - Performance } \\
\text { - Social networks }\end{array}$ \\
\hline $\begin{array}{l}\text { Aire fresco. Transmedia project that combines audiovisual and multimedia } \\
\text { arts so that the viewer can enjoy a complete, interactive experience, and enter } \\
\text { fully into a fictional world. The pillar of the project is an audiovisual piece, a } \\
\text { short film that tells the story of a family's journey from the city to the } \\
\text { countryside. The main reason for the trip is to take Isabel, the grandmother, } \\
\text { back to her home town, although the family takes the opportunity to spend a } \\
\text { few days together. Each family member does whatever they want. It is clear } \\
\text { that they are not a very close family and this trip seems to be an opportunity to } \\
\text { reinforce the few family ties that do exist. But the trip doesn't go as expected. } \\
\text { The personality of each family member and the long hours of the trip lead to a } \\
\text { change of plans sooner than expected. }\end{array}$ & $\begin{array}{l}\text { - Short film } \\
\text { - Website } \\
\text { - Videogame } \\
\text { - Social networks }\end{array}$ \\
\hline $\begin{array}{l}\text { Lia. LIA spend her live locked herself in order not to face complicated life } \\
\text { situations. A call will change everything, forcing her to leave the bathroom. }\end{array}$ & $\begin{array}{l}\text { - Short film } \\
\text { - Website }\end{array}$ \\
\hline
\end{tabular}




\begin{tabular}{|l|l|}
\hline & - Social networks \\
& - Comic \\
- App
\end{tabular}

Figure 6. Table with the project descriptions and the platforms developed

\subsection{2punt Ilibre. Transmedia company case study}

The idea for the 2puntllibre project was born in the GAM 3rd-year subject 'Multimedia script' and was carried out in the 4th year of the degree. The foundations of the project are based on fragmenting the story and reproducing it in different supports, with the idea of linking literature and technology. The project starts from a short story that takes place in the city of Girona. Each literary content was then translated into multiple platforms: audiovisual, illustration, interactive application, imaginary sound, performance, drawing, photography, website and comic.
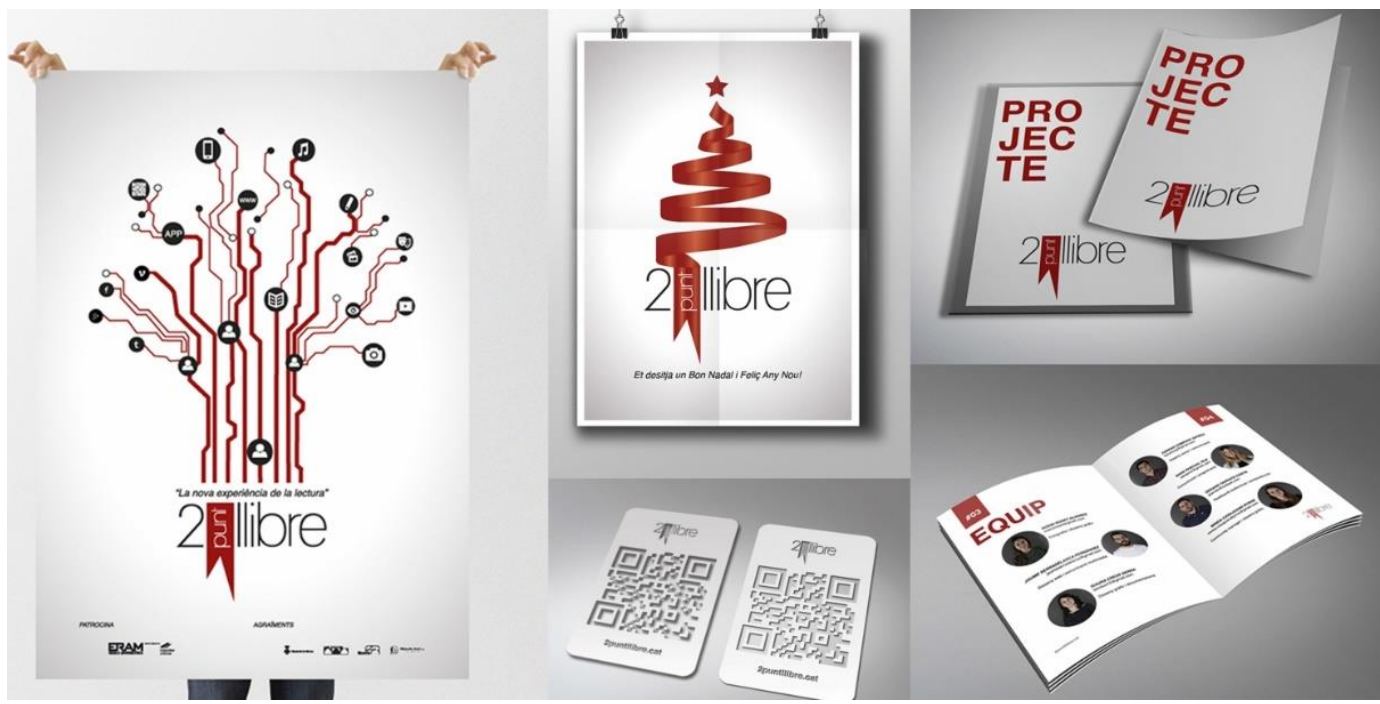

Figure 7. Graphical content of the project 2puntllibre 
The final result was an interactive tour around the city of Girona that took place in April 2014. A video summary was recorded of some people doing the tour, showing clearly the reasons for the application (See video here: https://vimeo.com/92866635).

The second phase of this project consisted in creating a business plan and setting up a company dedicated to ARG formats and content gamification. Thus, 'Fracktale' was born, a company that creates customized advertising campaigns characterized by using different media and technological platforms that complement each other to tell a story related to the contracting company.

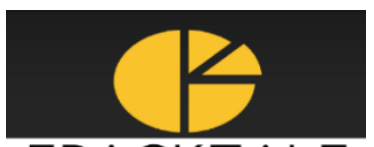

\section{FRACKTALE}

Figure 8. 'Fracktale' company logotype

Although it did not come to fruition, one of the proposals that arrived to 'Fracktale' was a project called '17', which intended to use transmedia narrative to expand the brands of 17 small Spanish cities. This case study illustrates how a transmedia company can be created: firstly, by designing an initial project; then, generating a business plan; next, establishing itself as a legal company; and finally looking for its first customers.

\subsection{Animal Hero. Transmedia nonfiction case study}

Animal Hero illustrates the ceaseless work of five students who had a very clear objective: to create a nonfiction narrative to help children with down syndrome. This project was also conceived in the $3 \mathrm{rd}$ year and developed in the $4^{\text {th }}$ year of the degree (2015); however, the team continues to work on the project today after 4 years of hard work. This project has received several awards and recognitions.

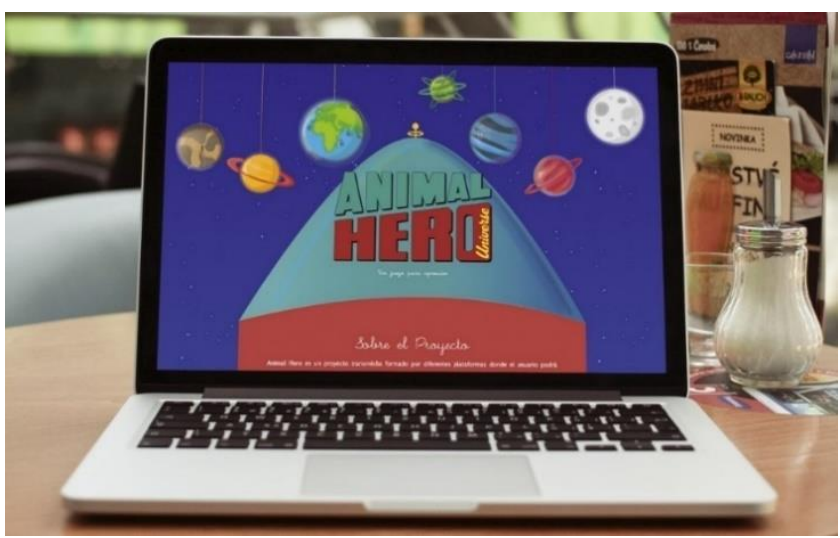

Figure 9. Animal hero website

In this case, this group created a brand called 'Growing games'. They now have access to the 'Santander YUZZ program' for entrepreneurs and are currently generating the business plan for their future company.

\section{Groving Games}

Figure 10. Logotype of the company 'Growing Games' 
Although they finished their degree a few years ago, the interesting thing is that the group has not dissolved and has in fact incorporated students from other degrees (the case of Aniol Batallé, a video game student at ENTI-University of Barcelona). A group of teachers also continues to help in mentoring this project.

\subsection{Lia. Transmedia fiction case study}

After some previous outstanding fiction projects, Lia is a recent project produced in the 4th year of the degree. This transmedia fiction project centres around a technically impeccable short film about a girl's fears and how she shelters herself in her bathtub. This work received the prestigious 'Laus Award', and therefore this group of students now face the professional world with a very valuable project as part of their university curriculum.

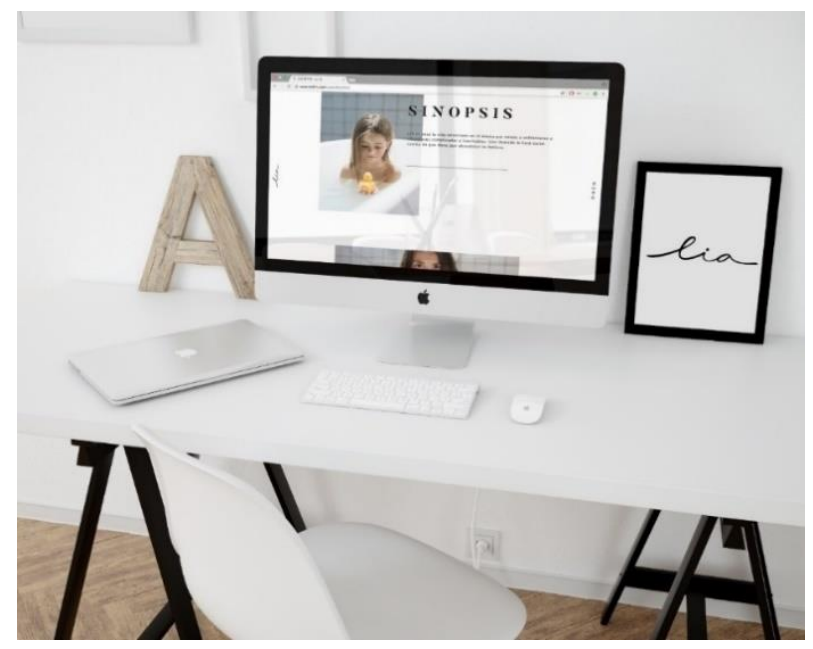

Figure 11. Lia project website

This is another objective of the students producing this type of project: to create the possibility that the students generate a significant and unique work that can be used to obtain jobs in the future.

\section{Assessment}

The assessment system for these kinds of projects is complex and difficult to regulate. Therefore, each year it is changed and adjusted depending on the types of groups and projects there are. Broadly speaking, the following is the continuous assessment process for these projects:

a) Normally, at the beginning of the course, each teacher gives three or four classes on their subject, introducing the subject and explaining the methodology to be followed. It is very important to show work from previous years in this introduction and explain in detail the dynamics that were established in previous years. Attendance can be recorded if considered necessary, both in the classes with the entire group and tutorials.

b) From this point, the teacher negotiates the tutorial dynamics with the students: time devoted to the different aspects, compulsory attendance of the entire group or a part of it, key items, delegating duties and work, etc. The teacher of each area should write weekly indications of the work requested in each tutorial, depending on each student's profile. It is important to assign specific tasks to all team members based on their specific role in the project.

c) Teachers discuss the progress of each group and the individual performance of each student in monthly meetings. Based on these indicators, adjustments are made in real time to support projects that are not being carried out in accordance with the initial planning. One of the most critical issues is to ensure that all projects are developed within the established time (as so many processes and follow-ups are involved). 
d) For the final evaluation, the information and weekly monitoring of each teacher (1st grade) has to be added to the final grade given to the project, which is one grade given to the whole group, and is awarded based on the quality of the transmedia project and the group report (2nd grade).

e) Finally, once the course is finished, it is compulsory to carry out an individual peer assessment. This activity involves filling out a form in which the specific skills of other members of the group are evaluated. This individual document is essential because it allows the teacher-tutor to detect issues that have been invisible to them for various reasons, especially as they have to teach between 4 and 6 groups of 6-8 people for a relatively long period of time.

f) Each teacher assigns a percentage out of 100 to each of these parts of the assessment (individual work, group project grade and peer assessment). The grade for the individual work and peer assessment is decided by each teacher, but the grade given to the group project is decided together. Some teachers reserve $10 \%$ of the final grade to assess the attendance at classes or tutorials, or they use it as recognition for certain students for their participation in discussions or group leadership capacities (or other indicators).

\section{Awards}

Although the methodology detailed here still needs to be refined and adjusted, there are positive indications of the acceptance and quality of the projects both nationally and internationally, as well as of the work placement of graduates. We list below the main awards received in recent years (2015-2017):

\begin{tabular}{|l|l|}
\hline Project & PRIZES - ACKNOWLEDGEMENTS \\
\hline Això nostre & - Finalist project of the European Youth Award 2015. \\
\hline Animal Hero & $\begin{array}{l}\text { - Project selected for the University-Industry Audiovisual Pitching } \\
2015 \text { (Clúster Audiovisual de Cataluña, first edition). } \\
\text { - European Youth Award winner } 2016 \text { (Smart Learning) } \\
\text { - Honourable mention edition II CPAC 2016 }\end{array}$ \\
\hline Desenterrant el negre & $\begin{array}{l}\text { - Winner of the comUNIca grants for the promotion of } \\
\text { audiovisual creation 2016 (CCMA, Sistema Universitario Catalán } \\
\text { and AGAUR, first edition). }\end{array}$ \\
\hline Lata de sardinas & $\begin{array}{l}\text { - Selected for the Interactive Digital Stories Track - Madeira Film } \\
\text { Festival 2017 }\end{array}$ \\
\hline Lia & $\begin{array}{l}\text { - Laus Awards 2017 - Audiovisual category (part of the } \\
\text { transmedia project) }\end{array}$ \\
\hline
\end{tabular}

Figure 12. List of main awards received in recent years (2015-2017)

In terms of professional work placement, statistics show that the skills obtained by ERAM graduates are necessary for most companies. Several reports show the very positive professional work placement possibilities of the GAM degree: according to the last two surveys about employment carried out by AQU Catalunya, $100 \%$ of GAM students surveyed are currently working. This study shows the high level of work placement and the quality of the studies.

\section{Conclusions}

As described and justified throughout this work, the University School ERAM has been committed for four years now to transmedia narrative based on audiovisual projects. The teaching method is innovative in terms of the following premises: a) groups formed by 6-8 students that work together according to a model that is very similar to the professional model; $b$ ) the student groups are joined by a team of teachers who act as supervisors for each area - coordination of the audiovisual area, coordination of the transmedia area, script, web design and development, editing, sound and postproduction - and who ensure the viability and quality of the projects; c) transversality with other subjects and courses is promoted; d) each team's needs are attended to in real time through regular weekly meetings between teachers; $e$ ) the school supports the presentation of the best projects at festivals and awards; and f) once the initial phase is completed, in some cases projects are continued through the ERAM Medialab, a spin-off of the school that aims to promote and refine certain chosen projects.

With the aim of improving this methodological proposal for future implementations, we plan to establish synergies with the Degree in Performing Arts (GAE) to introduce and enhance the fields of theatre, performance and installation in group 
projects, linking other departments and faculties of the Universitat de Girona in order to promote the production of multidisciplinary projects, develop projects commissioned directly by companies or projects that have a real application in companies, and generate spaces that are business incubators.

In the three case studies presented (and in others not described), it is clear how the construction of a project of this size is only the beginning of a larger project: in some cases, the project starts in the third year, it's developed in the fourth course and then the team continues to work on it to perfect it at other levels (visual, sound, code, languages, etc.). At the same time, a business plan is developed to turn the initiative into a real production company.

In short, the model proposed in the ERAM degree differs from other audiovisual and multimedia degrees taught in Spain as it applies a practical, project-based methodology involving multidisciplinary teams of 15-20 people, made up of students, teachers and professionals. All this directly affects the quality of the projects (as there is an expert supervisor for each area), the teamwork and collaboration, and the type of assessment and skills obtained by students at the end of the first half of the degree's fourth year.

\section{Bibliography}

[1] Agencia Ejecutiva en el ámbito Educativo, Audiovisual y Cultural (EACEA P9 Eurydice) (2011). Cifras clave sobre el uso de las TIC para el aprendizaje y la innovación en los centros escolares de Europa. Bruselas, Secretaría General Técnica.

[2] Cobo Romaní, C. and Moravec, J. W. (2011). Aprendizaje invisible. Hacia una nueva ecología de la educación. Barcelona: Colección Transmedia XXI. Retrieved from http://www.aprendizajeinvisible.com/download/Aprendizajelnvisible.pdf

[3] Creus, I.; Company, F.; Casajuana, M.; Roset, N.; Pascual, S.; Serradelarca, J. and G. Tarrats (2013). 2puntllibre [Transmedia work]. Retrieved from https://vimeo.com/92866635

[4] Escuela de Realización Audiovisual y Multimedia. Universitat de Girona (2016). Información general sobre el grado. Retrieved from http://es.eram.cat/estudios/grados-universitarios/grado-en-audiovisual-ymultimedia/descargas-de-documentos/

[5] Escuela de Realización Audiovisual y Multimedia. Universitat de Girona (2016). Website. Retrieved from http://en.eram.cat/

[6] Escuela de Realización Audiovisual y Multimedia. Universitat de Girona (2016). Website. Showroom. Final group project transmedia. Retrieved from http://en.eram.cat/showroom/c/treball-final-grupal/

[7] Escuela de Realización Audiovisual y Multimedia. Universitat de Girona. Información general sobre el grado (2016). Plan de estudios. Retrieved from http://es.eram.cat/estudios/grados-universitarios/grado-enaudiovisual-y-multimedia/plan-de-estudios/

[8] European Commission (2007). Key Competences for Lifelong Learning. European reference framework. Brussels: Commission of the European Communities.

[9] European Commission (2010). Information Communication Technologies: Work Programme 2011-121. Community Research and Development Information Service. Brussels: Commission of the European Communities. Retrieved from ftp://ftp.cordis.europa.eu/pub/fp7/ict/docs/ict-wp-2011-12_en.pdf

[10] Haddad, W. and Draxler, A. (2002). Technologies for education: Potentials, parameters, and prospects. Paris: UNESCO.

[11] Honey, P. and Mumford, A. (1986). The Manual of Learning Styles. Maidenhead, Berkshire: P. Honey \& L. Mumford.

[12] Kozma, R.B. (2005). National policies that connect ICT-based education reform to economic and social development. Human Technology, 117-156.

[13] Pérez Tornero, J.M. (2009). El nuevo horizonte de la alfabetización mediática. Telos, 79.

[14] Quera, S.; Peregrín, Y.; Vila-Clara, A.; Pujol, V.; Bosacoma, A. and A. Batallé (2015). Animal Hero [Transmedia work]. Retrieved from http://animalherouniverse.com/

[15] Red Eurydice. Comisión Europea (2011). La modernización de la educación superior en Europa 2011: financiación y dimensión social. Retrieved from http://eacea.ec.europa.eu/education/eurydice./documents/thematic_reports/131ES_HI.pdf

[16] Rovira, E.; de la Fuente, M.; Viña, M., Carreres, M., Pujol, J., Font, C., Torrents, A., Horta, P. and I. Iriarte (2017). Lia [Transmedia work]. Retrieved from http://www.liafilm.com/ 
[17] Strategic framework - Education \& Training 2020. European Comission. Retrieved from http://ec.europa.eu/education/policy/strategic-framework_en

[18] Torres Menárguez, A. (April 18, 2016). Universidades disruptivas, así se enseña fuera de lo convencional. El País. Formación. Retrieved from http://economia.elpais.com/economia/2016/04/15/actualidad/1460734714 976766.html?id externo rsoc=TW $\underline{\mathrm{CC}}$

[19] Universitat de Girona (2016). Plan de estudios de la Universitat de Girona. Retrieved from http://www.udg.edu/estudia/Matr\%C3\%ADcula/Guiadematr\%C3\%ADcula/tabid/13296/idpla/3157G0109/anyac ad/2015/language/es-ES/Default.aspx

[20] Wagner D. A. and Kozma, R. B. (2005). New technologies for literacy and Adult Education: a Global Perspective. Paris: UNESCO.

[21] Wagner, D. A.; Day, B.; James, T.; Kozma, R. B.; Miller, J. and T. Unwin (2005). Monitoring and Evaluation of ICT in Education projects: A Handbook for Developing Countries. Information for Development Program, infoDev. Washington: The World Bank. Retrieved from http://www.infodev.org/en/Document.9.pdf 